Kohl: a Journal for Body and Gender Research

Vol. 1, No. 2 (Winter 2015)

\title{
Becoming-Queer-Arab-Activist: The Case of Meem
}

\author{
Sarah Hamdan
}

\begin{abstract}
:
Drawing on the study-case of the Meem queer activist community in Beirut, I analyze the movements of deterritorialization and re-territorialization in the micropolitical flow of their located struggle. I intervene with the Deleuzian notions of becoming nomadic and affirmative politics of difference, the politics of location in the work of Rosi Braidotti, and Audre Lorde's notion of the erotic to think the becoming-queer-Arab-activist and map the complex processes of non-linear and differential becomings. My purpose is to conceptualize the non-linearity and the movement of the "different difference" of queer Arabness, which blurs the dialectical and identitarian binary of sexuality reproduced by the exotic Gay International and the exclusively discursive frameworks. I use these concepts to map the fluxes and the affirmative affectivities of desire in the Arab queer activism illustrated by Meem's non-identitarian approach.
\end{abstract}




\section{Introduction}

On June 26, 2015, the US Supreme Court legalized same-sex marriage in all states. Within minutes, my Facebook newsfeed was invaded by rainbow-colored profile pictures. There were three different tendencies among my Arab friends engaging with the topic. First, the celebratory group posted rainbow pictures and statuses with the \#lovewins hashtag; it encompassed Arab LGBT people, activists, supporters, militant atheists, as well as Islamophobes/secularists who condemned the backwardness of the Arab world and praised the West's "progress." Second, the critics (whom I would categorize as the Arab manarchists), the homophobic/sexist leftists, and the religious homophobes either mocked the rainbow-colored campaign (and hence homosexuality) or criticized gay rights activism in the Arab world because of its marginal political importance relatively to the "bigger issues." The third (minoritarian) group consisted of the Arab queer and feminist activists, including former members of the Beirut-based queer group Meem, ${ }^{1}$ which I used to be affiliated with. This group criticized the rainbow overdose with hashtags like \#abolishmarriage, denouncing the institution of marriage (from a materialist perspective), neo-liberal American imperialism, homonormativity, homonationalism, pinkwashing, racial wealth divide and exploitation of labor, exclusion and violence against transwomen, immigration policies, politics of respectability, progress narratives, and rights activism, etc.

This third (dissident) group later received negative reactions from the first group (the local LGBT activists) who considered them "party-poopers" (Saleh, June 27, 2015), with accusations of radicalism, academic elitism and classism, counter-productivity, and even homophobia. The party-pooper allegation (or feminist killjoys $^{2}$ ) is not unusual. But the accusation of homophobia/elitism, while unfounded, was difficult to argue against in online platforms: polarized readings mistook the stance of some of us for that of the homophobic and heteropatriarchal oppressive forces in the Arab world. In this position of congruence, the sense of discomfort persists, as many anti-imperialist (and especially US-based diasporic) scholars accuse local gender and LGBT activists in the Arab world of being complicit with Western hegemony. ${ }^{3}$ I agree with AbuOdeh's critique of anti-imperialist scholarship; hence, I do not want to dismiss the work of local LGBT activists. At the same time, I do not condone some of these activists' problematic views.

\footnotetext{
${ }^{1}$ Meem no longer exists in the form of an "organized" support group since 2014 as it did from 2007-2014. When I speak of Meem in this paper, I am referring to the aggregation of the previous members of Meem who currently form an "informal" queer activist community/network in Beirut, and who are engaged in diverse activist projects for the time being.

2 I borrow the term "feminist killjoy" from Sara Ahmed (2010).

${ }^{3}$ Abu-Odeh (May 5, 2015) criticized the US-based anti-imperialist academics who consider local gender and LGBT activists in the Arab world as being complicit with Western imperialism. These scholars are often diasporic Arabs, from upper-middle classes and often have a patronizing tone with regards to the "naïve activist" reproducing empire. AbuOdeh also points out that these critics often do not have a history of political activism or persecution/exile, but rather benefit from the same US (academic) capital/prestige that they criticize. Furthermore, there is an undeniable affinity between the position of the US-based anti-imperialist academic and the position of the local political nationalist/lslamist; both are silencing gender and sexuality oppression.
} 
This paper functions as a nomadic writing attempt to think through these "areas of silence" and the "strong connection to a radical non-belonging" (Braidotti, 2011, p. 44) that I experienced when I tried to articulate and imagine an Arab queer movement that does not conform to the majoritarian 4 binary represented by the first and second group. The "different difference" in the politics of the queer activists seemed to be silenced and erased by both the pro-equality LGBT activists and by the homophobic camp. ${ }^{5}$ First, I critically engage with Massad's critique of the Gay International and distance my queer Arab project from discursive and identitarian frameworks that exclusively rely on the critique of the West. Second, I untangle the concept of becoming and desire in Deleuze's philosophy of difference, and Lorde's notion of the erotic, which are contrasted to the exotic. Then, I relocate Arabness not as an identity, but rather as the politics of location that brings forth the erotic desire and the process of deterritorialization. Finally, I argue that the binary West/Arab is an image of thought in the paradigm of erotic/exotic.

The mapping of deterritorialization, positive intensities, and relationality in the Meem activist encounter unsettles exotic frameworks of identity and dialectics. Introducing Deleuzian concepts of becoming, ${ }^{6}$ alongside Audre Lorde's notion of the erotic, is capable of capturing the "different difference" of queer Arab activism, which is the non-exotic erotic. Therefore, how can we read the power of the non-exotic erotic against the idea of a culturally authentic sexual identity?

\section{Shifting from the Critique of the Gay International}

Joseph Massad's work Desiring Arabs (2007) is among popular postcolonial scholarship on sexualities in the Arab world. Massad criticized the universalizing and hegemonic discourse that Western LGBT human rights

\footnotetext{
${ }^{4}$ The Deleuzian notion of the majoritarian (or molar) politics is understood as the framework of the white, liberal, phallogocentric male that reproduces the logic of the dominant hierarchal and normative types of political approaches, deploying a linear axe of time. In contrast, the notion of minoritarian/molecular is the non-essentialist, non-identitarian and flowing political movement in the form of affirmative becoming (Braidotti \& Dolphijn, 2014, p. 27)

${ }^{5}$ Following the recent US Supreme Court decision, the Ramallah-based artist Khaled Jarrar painted a rainbow on the Israeli separation (Apartheid) wall on Monday, July 29, 2015. He defended it by stating that this work is an "expression of support for the freedom of the occupied Palestinian people" (Shams, June 30, 2015). By Monday night, the rainbow flag was painted over with white paint in a public procession. Some people considered the artwork disrespectful to the Palestinian prisoners in Israel, given that there is a nearby graffiti demanding their release. The supporters of this position were often articulating latent and explicit homophobia. Al-Qaws, a Palestinian queer group involved in antiPinkwashing activism, issued a statement condemning the statements of the homophobic Palestinian activists (AlQaws, June 30,2015). At the same time they questioned the choice of rainbow graffiti and the lack of attention given to their local 10-year-old queer activism and their feminist and anti-occupation politics, which have been radically different from the Western LGBT movement.

${ }^{6}$ I acknowledge that many postcolonial scholars such as Trinh Minh-ha, Audre Lorde, bell hooks, Gayatri Spivak, Gloria Anzaldúa, Frantz Fanon, and Edouard Glissant have addressed the concept of difference and hence could potentially be useful for theorizing a non-identitarian Arab queer subjectivity. This paper, however, is limited to an engagement with the philosophy of Deleuze/Braidotti while bringing in Audre Lorde's notion of erotic, and hence might be accused of extensively relying on Western philosophers instead of centering feminists of color. While this critique is legitimate, I go beyond West vs. East dichotomies by using the theoretical frameworks I found most pertinent to this paper.
} 
organizations engage in, which he coined as "the Gay International." The Gay International works through a Foucaudian framework of "incitement to discourse," in which Orientalist discourse epistemically and ontologically imposes the universalization of the categories of homosexuality/heterosexuality. He criticized the complicity of Arab LGBT activists in this imposition of a universal homosexual identity (along with the resistant homophobia), which does not belong to pre-colonial Arab culture, since the binary of homosexuality/heterosexuality is a product of Western modernity.

Recently, many scholars and activists have problematized Massad's assertion of cultural authenticity to Arab sexuality (Abu-Odeh, 2015; Amer, 2010; Anderson, 2010; Habib, 2007; Hamdan, 2015; Makarem, 2009; Taha, 2013). Massad claims that the Gay International is implicated in the politics of Arab LGBT groups, which is obvious in the supportive reaction of the local Arab LGBTs to the US pro-equality discourse. However, there seems to be blind spots in his analysis: his critique does not take into account the complexities and non-homogeneity of the LGBTQ groups in the Arab world, as illustrated earlier in the disagreement on social media between the local LGBT activists and Meem activists. It is also incapable of conceptualizing Arab subjectivities outside of the discursive and identitarian framework of complicity with the West (Hamdan, 2015). To avoid the dichotomizing of sexuality discourses between that of the Western Gay International and that of the Other, I do not venture to say that there are uncontaminated/authentic, precolonial subjectivities. I draw on Deleuzian poststructuralist conceptualizations of subjectivity as non-unitary, non-identitarian, and multiplicitous, based on hybrid and material-semiotic relations between human and nonhuman bodies.

I consider Massad's critique as an analogous political project to the works of Talal Asad and Saba Mahmood (Asad, 2003; Mahmood, 2005), who mainly focus on challenging secular/liberal principles and the Orientalist discourse on Islam in the West. Although I join their effort of reconceptualizing agency and exposing colonialist/secular discourses in the Arab world, their works seem to be located primarily in a Western geopolitical context. In contrast, I situate my queer Arab project first and foremost in a non-Western geopolitical framework that attempts to be non-dialectical and non-identitarian. In other terms, this project is embedded and embodied by different geopolitical knowledges on the material and discursive levels. In particular, it is concerned with a type of majoritarian politics located in the Arab world - namely, the oppressive ("homophobic") forces - that are definitely entangled with the Western hegemonic majoritarian politics. However, Arab majoritarian politics cannot be adequately mapped from a materially Western location that is disengaged from local activists' politics and the power-relations grounding their knowledges. 


\section{Articulating a Different Difference in the Exotic/Erotic Paradigm}

Deleuze and Guattari (1980) define becoming as the production of a new assemblage, carrying nonsymmetrical double de-territorialization. ${ }^{7}$ The becoming does not have a subject separate from itself, and there is no goal that is distinct from the block of becoming; rather, change occurs by the entry into the new assemblage. The concept of becoming destabilizes the understanding of identities as being fixed categories that are coherent and that are expressions of the self (Walker, 2014, p. 50). It rather emphasizes how the proliferation of identities and movements is an ontology of difference, which does not see being, but being in process in a nomadic subjectivity. ${ }^{8}$ I understand the ontology of becoming as constituting more than a nonidentitarian claim. It indicates a temporality which does not see time as a chronological counting of moments, but rather as a durational succession of change which sees distinct moments or the present itself as a becoming (Ibid, p. 50).

In his preface to the Anti-Oedipus (2009), Foucault engages with Deleuze and Guattari's thought by addressing the importance of introducing desire into thought, discourse, and political action. He asks: "how can and must desire deploy its forces within the political domain and grow more intense in the process of overturning the established order?" (2009, xii). He claims that developing desire ${ }^{9}$ by proliferation, juxtaposition, and disjunction is crucial, as opposed to subdivision and pyramidal hierarchization. This understanding of desire in Deleuze and Guattari's ideas resonates with Audre Lorde's understanding of the power of the erotic. Lorde (1984) unsettles both the imperialist and the patriarchal/heterosexist hegemonic powers. She disentangles eroticism from its patriarchal and colonialist uses, which she calls the pornographic. The pornographic is the suppression of the power of the erotic and of true feeling (Lorde, 1984, p. 88). She talks about the oppressive separation of the erotic demand from the vital areas of life other than sex, which hold the political and creative energies. She refers to two false dichotomies that have been concealing the erotic knowledge: that the spiritual/emotional is separated from the political, and that the spiritual/emotional is also separated from the erotic.

\footnotetext{
${ }^{7}$ Deleuze and Guattari use de-territorialization to designate the displacement of identities, persons, and meanings and locate a defamiliarization that enables imagination for a potential community, even as it produces alienation (Kaplan, 1987, p. 188).

8 Inspired by the work of Deleuze, Braidotti recognizes nomadic subjectivity as non-fixed, non-unitary, and nonessentialist. She uses the figuration of nomadism to indicate movement, transformation, multiplicity, and disidentification from sedentary phallogocentric philosophical thinking (2011, pp. 22-24), which is what Deleuze described as de-territorialisation. In contrast to the dualistic models of social constructivism, a nomadic approach perceives the body as "a threshold of transformations [and as] multifunctional and complex, as a transformer of flows and energies, affects, desires, and imaginings" (Braidotti, 2011, p. 25). Nomadism is a non-essentialist view of subjectivity in the post-structuralist philosophy of difference, which draws attention to feminist approaches to embodiment.

9 Deleuze and Guattari understand desire as not subjective, and as being different from the hankering after what we don't have; in other terms, desire is not oriented towards lack. It is rather the process of relationality and enjoyment of flows of matter and forces streaming through bodies in networks of production (2009). Moreover, social assemblages are considered to be "compositions of desire," and "desire has nothing to do with a natural or spontaneous determination; there is no desire but assembling, assembled, desire" (1980, p. 399).
} 
The erotic is in this sense a bridging force that emanates from an unexpressed or unrecognized feeling and that seeks the

assertion of the lifeforce of women; of that creative energy empowered, the knowledge and use of which we are now reclaiming in our language, our history, our loving, our work, our lives (Ibid, p. 89).

The assertion of life in the power of the erotic evokes Deleuzian desire, to which Lorde assigns the ability to increase relationality and sharing capacity. As shown later with the discussion, or encounter, between former Meem activists, establishing physical, intellectual, emotional, or psychic connections through the erotic makes it more possible to understand others, not only through the similarities, but also through their differences and what they do not share (Ibid, p. 91). Likewise, erotic knowledge pushes the feelings of suffering and despair from the experience of oppression away from powerlessness and self-denial. It leads them instead towards the drive to organize a collective and to create solidarity in a feminist practice.

It is necessary to dwell further on the notion of erotic by separating it from the exotic. Mascat (2015) develops a notion of "postcolonial exotic" in which there seems to be a constitutive ambivalent function of (re)production of Otherness. This function reproduces the same exotic logic - even though this Other (the authentic Arab) appears to be different from the Western Gay International - and is subordinate to dominant neo-orientalist discourses that preserve the West/East binary. In this sense, there is a need to make the erotic resistant to Orientalist imperialism, and to recode it against the power of comfortable exoticism that seeks uniformity over different difference.

A Deleuzian philosophy of nomadic becoming is useful to articulate a sexuality politics that escapes the exotic binaries of Gay International/authentic Arabness, and West/Arab. Re-imagining the encounter with difference can emanate from the power of erotic desire. It can also attempt to conceive of Arab queer difference as escaping the economy of the same and the phallogocentric modes of recognition (Grosz, 2005) that the binary of West/Arab is trying to impose.

\section{Becoming-Queer-Arab-Activist ${ }^{10}$}

\section{a. Relocating Arabness}

The starting point of a materialist non-identitarian feminist politics that criticizes the universal humanist subject of the Gay International is the immanent regrounding or the politics of location. This method articulates the

\footnotetext{
10 The phrase/concept "Becoming-queer-Arab-activist" is inspired by the hyphenated concept "Becoming-minoritarian" (or "devenir-minoritaire") from Deleuze and Guattari. The use of hyphens emphasizes the ontological feature of dynamism characterizing the notion of becoming, and avoids the connotation of teleological arrival in favor of asymmetrical motion and constant destabilization of identities that is always unfinished. In this sense, Meem activists are not becoming queer Arab activists, they are always a becoming-queer-arab-activist(s).
} 
different difference (an Arabness, I claim) by combining epistemological with political accountability while avoiding the pitfall of relativism (Braidotti, 2011, p. 15). Politics of location analyzes the multiple power locations that the queer Arab subject inhabits along modalities of relationality inside and outside the Meem community. The collective activity is connected to two notions: memory and narratives (Ibid, p. 16). These notions activate the process of bringing a location that is collectively constructed into symbolic representation. Hence, I refer to Arabness as a location of imagined communities, culture, language, and history (Joseph, 2012). Braidotti explains that politics of location is the process of consciousness-raising that involves a critical, self-reflexive, and relational feminist knowledge production. In Deleuzian terms, it is the process of deterritorialization, in which the subject is estranged from the familiar and is immersed in the collective reimagining of queer Arab activism. ${ }^{11}$ In Foucaudian terms, this process is called micropolitics, which is a reflexive self-making revolving around narrative practices (Leurs, 2012, p. 27) and reclaiming erotic desire, such as the narratives that were told during the encounter with Meem activists. In this sense, reclaiming Arabness (and inhabiting it) as a politics of location for the subject is an attempt to reinvent a collective imaginary in a non-essentialist and non-relativist manner. Arab subjectivities are a process of constant flows and fluxes where normative power discourses are de-territorialized and then re-territorialized along affirmative affectivities that transform the negative into positive passions (Braidotti, 2011, p. 18).

Meem activists are situated within this process of de-territorialization, which becomes a location of Arabness and "embedded and embodied memory" (Braidotti, 2006, p. 29). Meem was a Beirut-based and queer support group for lesbian, bisexual, queer, and questioning women, as well as trans* people, from 2007-2014. It was actively working for the empowerment of women and community building. Meem adopted a strategy of relative or "ambiguous invisibility" (Lynn, December 12, 2010): since it was a closed and safe group, it neither focused on legal change/LBT rights discourse, ${ }^{12}$ nor on public events. Rather, the group's feminist approach challenged the division between outness/closetedness and visibility/invisibility that are reinforced by Western LGBT discourse based on the post-Stonewall model of coming out of the closet (Moussawi, 2015). Furthermore, it relied on the critique of systems of oppression, such as patriarchy, racism, sectarianism, heteronormativity, Zionism, classism, rather than using a legal framework for organizing. For instance, BDS activism (the campaign of Boycott, Divestments and Sanctions against Israel) and reclaiming the Arabic

\footnotetext{
11 This Deleuze's concept of different difference/de-territorialization resonates with Bhabha's notion of the unhomely. Bhabha (1992) talks about home and the sense of belonging by drawing on Freud's concept of the uncanny or unhomely, which refers to the estranged feeling of encountering something familiar yet frightening which remains in an intimate sphere. Bhabha explains that the sense of belonging is de-stabilized through the notion of unhomely, because it is not the opposite or the lack of having a home. The boundary between home and world is displaced; the unhomely is the in-between space between the world and home, between public and private.

12 In Lebanon, although article 534 of the penal code is used to criminalize "sexual acts against nature," and hence homosexuality, there have been two recent court rulings that have concluded that "homosexuality is not unnatural" (Kilbride, March 8, 2014). At the same time, there have been a few police raids targeting working class and migrant (gay) men in a Hammam and a cinema. Moreover, the gender non-conformity of transfemmes makes them more vulnerable to police violence, and it is linked to misogyny, which also targets cis-women. Hence it is important to perform a class and gender-sensitive analysis (inclusive to transwomen) when addressing the specificities of the Lebanese legal system with regards to homosexuality. The "natural sex" approach is problematic.
} 
language through writing about sexuality in Arabic (instead of the more accessible/imperialist English or French terminologies) are crucial parts of Meem's politics. ${ }^{13}$ These strategies connect it to the embedded and embodied politics of the Arab region through the power of the erotic, and distance it from the depoliticized and universal Gay International of the exotic realm.

The underpinnings of the erotic locatedness explored above bring forth a definition of queer Arabness. In other words, queer Arab subjectivities are always becoming once they are perceived outside the framework of exoticizing authenticity. I consider becoming-Arab as a "vitalistic yet non-essentialist brand of immanence that bypasses liberal individualism and dislocates the anthropocentric bias of communitarianism" (Braidotti, p. 152). In my project, Arabness is neither an essentialist nor a romanticized position; it does not refer to a pre-existing authentic identity, and it is not interested in opposing the West or Islam. The notion of Arabness is loaded with a multiplicity of possible meanings. I use Arabness instead of Lebanese to define it as political subjectivities-in-becoming.

\section{b. The binary of West/Arab as image of thought in the paradigm of erotic/exotic}

The notion of queer Arabness points to the need for new mappings for a queer sexuality based on a nomadic and erotic approach to desires and pleasures rather than a "liberation through sexuality" strategy of identity politics (Braidotti, 2011, p. 285). The binaries reflected in the reactions to the legalization of same-sex marriage in the US and the Gay International argument epistemologically and ontologically draw on the oppositional forms of sexualized Western and Arab subjectivities. Drawing on Deleuze's work and Lorde's notion of the erotic, these binaries should be considered as "images of thought" or exoticized forces that suppress the erotic.

"Images of thought" are affective orientations that become dominant in societies and accepted as truth or common sense. They are "dogmatic, orthodox or moral" and "distorting" (Deleuze, 1994, in Al-Nakib, 2013, p. 466), and limit the proliferation of bodily affects. ${ }^{14}$ However, they are different from the notion of ideology. Images of thought are ideas in Arab societies about homosexuality being abnormal (Marks, 2015), and that sexual subjectivity is confined within the dichotomous framework of West/East (as well as

13 To read more about Meem's involvement in the BDS movement for instance in the campaign in 2011 that called on IGLYO's Member Organizations to respond to the BDS call and boycott Israel, check: http://www.bekhsoos.com/2011/06/call-for-iglyo-member-organizations-vote-no-to-iglyo-in-israel/. Bekhsoos often published articles and poetry in Arabic, and addressed the importance of writing in Arabic and re-inventing it, by either creating or reclaiming words. For instance, the contributor of the article "Gayifying Arabic" insists on the need to practice the use of Arabic in communication and in knowledge production about gender and sexuality: http://www.bekhsoos.com/2010/05/gayifying-arabic/

14 The notion of affect according to Spinoza is the bodily capacity to enter modes of relation with multiple others, and constantly affecting and being affected by them. Gregg \& Seigworth define affects as arising "in the midst of inbetween-ness: in the capacities to act and be acted upon. Affect is an impingement or extrusion of a momentary or sometimes more sustained state of relation as well as the passage (and the duration of a passage) of forces or intensities" (2010, p. 1). 
homosexual/heterosexual, man/woman, etc.). How do we articulate a form of political activism without reiterating the dialectics of negation and images of thought? Deleuze considers that negation is a Hegelian understanding of subjectivity and that it reduces identities to a false framing which hinders our capacity to understand the multiplicity of affirmative difference of subjectivities (Lalor, 2015, p. 11). Thus, an Arab queer activism should not start with a negation and must not reiterate the binary of West/East. Rather, it should engage with the problematic or the multiplicity of difference. As such, identities and the binary of West/East are a false problem. Identity politics that defines activism against the Gay International in the aim of opposing dominant imperialist frameworks are obscuring positive queer Arab "different differences" that could produce more differences (Deleuze, 1990, in Al-Nakib, 2013).

However, the productive potential that is directly linked to the capacity of rights paradoxically occupies two different and oppositional positions at the same time, and this surplus could be conceived as an immanent operation of rights existing as an unactualized element (Lalor, 2015, p. 12). This paradox of rights could be illustrated in the images of the $\mathbf{2 0 1 5}$ gay pride in San Francisco versus in Istanbul, where the police fired water cannons and tear gas on the participants on June 29th. In each of these two different locations, rights should be seen as active processes interacting with moments of dynamism in different cases (lbid). This argument could complicate the non-legal and non-rights-based approach that Meem activists deploy.

In 'Openings:' A Political Movement in Lebanon? A Conversation on Feminism and Queerness" (2015), Sanaa H. published excerpts from a discussion session held on May 2015 between five former members of Meem and the feminist collective Nasawiya. The conversation touched upon the experiences and opinions of the participants on the crises and failures of the queer feminist political movement in Lebanon, the values of collective organizing, and also the personal relationships constituting the queer community (Sanaa $\mathrm{H}$., 2015). While the discussion is not representative of the group at large, it presents some of the many narratives that are claimed by former members of Meem.

The queer activists in the encounter stated that although there were disagreements, Meem did support certain rights and legal organizing:

we never failed to support human rights legal organizing, like the bill for the protection of women from domestic abuse, in spite of the critiques some of us had about it, and we were ready to go on a hunger strike to pressure for its passing. Maybe radical acts come from particular tactical goals? (Sanaa H., 2015, p. 97).

Sanaa challenges the idea of cultural authenticity by de-territorializing political locations from fixed patterns of objectives and results:

Meem was a political and a politicized place. And maybe what gave Meem a particular identity was the absence of a traditional written goal that characterizes the work of associations and movements (lbid). 
How do we make sense of such paradoxes, for instance the support of rights in a non-rights-based approach? And how can we think of the notion of "absence of traditional written goal" that Sanaa articulated as a nonidentitarian becoming?

\section{c. Becoming-Nomadic-Queer-Arab-Activist through paradoxes, disagreements, proliferation of differences}

The process of becoming a nomadic queer Arab subject is neither a dialectical opposition, nor an unfolding of an essence of Arabness in a teleological manner. Nomadic becoming is rather an "affirmation of the unalterably positive structure of difference, meant as a multiple and complex process of transformation, a flux of multiple becomings, the play of complexity, or the principle of not-One" (Braidotti, 2006, p. 145). "Thinking Arab queer subject" is neither the expression of an Arab (or queer) in-depth-interiority, nor the enactment of transcendental consciousness. Becoming is a process of affectivity and imagination that empties and opens up the self to possible encounters. It makes the subject receptive to the assemblage of bodies, ideas, things, and political institutions. It rests on the spatio-temporal coordinates, mobilizing "one's capacity to feel, sense, process and sustain the impact with the complex materiality of the outside" (Ibid, p. 145). This understanding of Spinozist materialism is non-transcendental and dynamic, and allows us to move away from purely discursive formations; it maps the collective imagination and the shared desires in the constitution of the subject (Ibid, p. 147).

Meem's encounter captures this "floating attention [and] fluid sensibility that is porous to the outside" (Ibid, p. 146). The participants in the discussion often disagree with each other and bring in different approaches and ideas from the past, present, and future on how to build a movement and a community. They question whether they ever were a movement and whether or not they should be one (Sanaa H., 2015).

In trying to think what a political movement in Lebanon is, Ghenwa emphasizes its "fragmented and divided" nature (Sanaa H., 2015, p. 94), while Qid voices their disagreement and considers that they are not a political movement, mainly because Meem was an organization that appealed only to middle and upper-middle classes. Qid deploys their erotic desire against exotic hierarchization of classism and insists on making class as part of the sets of multiple and complex political domain of their activism:

Honestly, I do not see a political movement in Meem or in Nasawiya. Actually, the only action that I called movement, was the campaign for "toppling the sectarian regime" because it was the only one in which I felt I might find my mother walking in. The criterion for me was always: Does my mother participate in this movement? My problem with the "secular march," or even with Nasawiya or Meem or Helem, is that their speech only addressed a certain class and enforced particular class criteria asking people to "rise" to them (Sanaa H., 2015, p. 95).

On the issue of language and the class connotations associated with the use of English at the expense of Arabic, Qid deconstructs Meem's apparent politics of using Arabic: 
To me, and to everyone from a particular background, where we do not use any English words at home for example, I had to keep up with the requirements and the lifestyle of the middle and uppermiddle class even, to find myself a place in what is called a "political movement" (Ibid).

Alissar disagrees and asserts that Meem was a political movement "because it created people who are skilled in many fields, and who are from diverse backgrounds, and it brought them together;" she also mentioned the international influence of Bekhsoos and Bareed Mista3jil (lbid, p. 98). The disagreement between Qid and Alissar on whether Meem was a political movement unravels the micro-movements of energies that multiply meanings, and most importantly that do not look for uniformity of meaning. This is how the ontology of becoming operates. The notion of a fixed political movement as envisioned by identitarian frameworks resides within dominant discursive-material spheres and is embedded in patriarchal and hegemonic norms. In contrast, thinking of political movement as a becoming is capable of encapsulating these paradoxes that Qid and Alissar illustrate. Coupled with the lack of coherency mapped in the architecture of becoming-queerarab-activist, they demonstrate the need to abandon our perception of a whole.

In fact, Jo emphasizes the non-identitarian aspect of the political movement and expresses the revolutionary productivity of flows and differences:

the "movement" should overcome the limits of identity politics. I mean any movement should take into account the possible differences in the identity politics of its members, without making these identities one of its goals (Ibid, p. 94).

Lynn de-territorializes their previous fixed meanings of political movement and moves towards a proliferation that enables the imagining of a new community:

I underestimated the importance of building a community. But today, I think, it may be impossible to build a movement without building a community for it (lbid).

At this point we are shifting from a discussion on political movement (and its paradoxes) towards a focus on the importance of community for this political movement. Sanaa moves on by overturning the definition of feminist politics and by positively multiplying differences of meanings of political activism (or "political act") rather than negating them along a dialectical model. This multiplication of meanings in Sanaa's definition involves micro-movements that are not captured by identitarian and discursive formations. She links politics to solidarity and consciousness, which also depicts the notion of the erotic. She hence deploys the forces of erotic desire to increase relationality:

For me, feminists coming together is a political act. At first, defining oneself as a feminist, and secondly, exchanging support and solidarity on all levels, are also political acts. Plus, engaging in discussions as self-conscious political identities, and articulating this consciousness openly, is a political act (lbid, p. 100). 
Remarkably, Sanaa continues by alluding to the creative and positive process of becoming, driven by an affective and erotic feeling of constant hope. The ontology of difference affirms a continuous flow of desire without being lacking, as a shared notion of an imagined community bridges that gap:

I think what brings us and keeps us together is our constant hope of building a political movement. We are a community and we come to each other a lot of the times, to work on things related to Meem. It is not only community that keeps the movement going. It is also the movement that keeps the community going and cohesive.

In a presumably unorganized structure, the erotic desire is coupled with de-territorialization to differentiate between the micro and macro levels of political organizing. While micropolitics rely on internal communities to subvert the space of the exotic, macropolitics are entrenched in fixed modalities of organizing:

So now we are talking about two levels of politics, the first is the small political and grassroots community, and it is usually unorganized; and the other is a larger political movement built on strategic alliances and not tactical goals, and it is usually organized and structured (lbid).

In these excerpts, the Meem activists are thinking new concepts by attempting to define the notion of political movement and community, and actualizing virtuality within the specificity of the actual context of Beirut. The articulation of paradoxes, disagreements, proliferation, and absence of goals should not be seen as negative; it is precisely the micropolitical and nomadic cultivation of the virtual that is experimenting with positive intensities. Affect, therefore, triggers the process of becoming by rupturing identitarian spaces dominated by hegemonic structures of organizing and movements.

\section{d. "Feeling Queer Arab/Brown, Feeling Down"}

A Deleuzian account of activism enables and imagines a narrative of being/becoming that not only resists the pull of identitarian frameworks of relationality, but that also considers "feeling queer Arab/ brown" as an ethical position of becoming (Muñoz, 2006). From the question of "Can the Subaltern Speak?" famously asked by Gayatri Spivak (1988), I want to shift the focus to the questions of "How Does the Subaltern feel? How might subalterns feel each other?" (Muñoz, 2006, p. 677). This is particularly relevant to the queer activist community in Beirut, which can be perceived as subaltern to the majoritarian Western imperialist and nationalist discourses.

The ways in which the community in Beirut is "feeling brown, feeling down" and experiencing depression and disappointment should be seen as a modality generated by affective particularities coded to racial subjectivities (Ibid, p. 679). Arab (queer) subjectivities' affectivities and modalities of depression belong to the minoritarian sphere. In addition to their feelings of anger and depression, what is also interesting to 
highlight in the encounter is the frequent narration among some of the participants of the mistakes and the failures of the political movement. As Lynn puts it:

we built a community of queer women and trans* people and feminists and all that. And it was an alternative community to a certain extent. But if we want to talk about a movement, we have to think of our coalitions and our relations with other groups and issues, and I don't think we succeeded in that. We did gain a certain "legitimacy" in the eyes of these organizations [...]. But have they ever talked about queer issues? About queer lives? Our issues were silenced in their meetings, even when we were present (Sanaa H., 2015, p. 103).

The failure in strategies of queer activism should be framed as an encounter, which is a moment that pushes us to think rather than to act along images of thought or pre-ordained practices (Deleuze, 2011, in Lalor, 2015 , p. 13). It is in this moment that images of thought could be disrupted and where the potential actualization of a queer Arab becoming could be seen. Qid expressed their feelings of disappointment:

I feel hurt when some of us link the fate of the political movement to the end of Nasawiya or Meem for example, because then it makes it revolve around us only (lbid, p. 95).

Lynn also criticizes the previous strategies of Meem:

We lived in an illusion that we are different from NGOs [...]. We were working within a certain hierarchy, even if it was invisible, and we were getting funding (lbid, p. 96).

Moreover, Ghenwa thinks that Meem's strategies were not radical enough:

I think the reason why we failed is that we did not take risk with ourselves or our bodies, we did not go out to the streets and we did not vandalize. We were a comfortable movement leading a comfortable, safe struggle. [...] we were nice feminist activists within the accepted framework (lbid).

The Deleuzian event is neither material nor actual, and cannot be anticipated; it consists of a virtual movement (Reynolds, 2007, in Lalor, 2015, p. 14). Furthermore, encounters determine new relations, which can then be actualized and released through events. Becoming is captured in the extraction as well as the repetition of singularities in new combinations that have not been thought. This process could be described as the "repetition of the future, the reiteration of the new" (Lalor, 2015, p. 15). In this sense, thinking the possibility of a queer Arab activism would resonate with a re-thinking of "different differences" through relationality, confusion, and acknowledgment of failure. 


\section{e. Thinking Arab Queer "Different Differences" in Time}

In the notion of event and encounter, Deleuzian temporalities are useful in understanding future Arab queer becomings as the actualization of virtual events or the "memory of another past" (Al-Saji, 2004, in Lalor, 2015, p. 16). As such, in the Meem encounter, the participants narrate the timeline of the movement by listing the numerous stages and changes that happened on the political and personal levels. These processes of micropolitics between different forces remain continuously unstable, undetected, and always shifting in time. Instead of the politics of visibility, queer activism in the Arab world should engage in the politics of imperceptibility, which involves forces that generate transformations through categories of action, not of subjectivity (Grosz, 2005, in Lalor, 2015, p. 17). In particular, becoming-imperceptible is what Braidotti understands as the eruption of events that mark new political ontologies and that construct sustainable futures (Braidotti, 2006, p. 152).

In the case of Meem, while the participants are engaged in imperceptible politics that questions notions of visibility, they also engage in debates about inclusion/exclusion. Meem's actions are characterized by constant movement. Movement, forces, and intensities in an action are the modes of becoming, and these modes differ from the ones in identity politics. Seeking movement and uncertainty in a politics of imperceptibility or sphere of micropolitics (of their everyday lives) could actualize the virtual queer Arab movement. Meem activists seem to be embodied and embedded entities that are immersed in a web of fluxes, interactions, and affective negotiations with themselves and with other entities. For instance, Lynn shares a feeling of paralysis, which I consider as a bodily affect flowing its erotic forces towards a disentanglement from racist and nationalist politics through the understanding of differences. The increased intensities shifted Lynn's erotic knowledge towards de-territorialization of pasts, and these creative political energies could move and actualize an Arab queer activism:

Personally, at the moment I feel a kind of paralysis primarily because of the general political situation. Look at what's happening in this country, on the borders with Syria and occupied Palestine, and in Syria and Egypt. If we do organize ourselves, what will we do? Based on what causes? How will our struggle on issues of sexuality, for example, look like, in a context that is changing very fast, and where the future does not look clear or simple? Priorities have changed (Sanaa H., 2015, p. 101).

The engagement with the temporality of their queer movement seems to be desiring a vibrant and empowering present, and is therefore living in intensity and unfolding possible futures (lbid, p. 154).

Nevertheless, there seems to be another risk that should be accounted for. The actualization of the possibility of these futures rests on thinking the affective and collective forces of the present (Braidotti, 2009, in Lalor, 2015, p. 8). While this generative approach to the forces of thinking the present is pivotal, there is a danger that such future promises of an "Arab queer becoming" become trapped by "images of thought" and "happiness scripts" (Ahmed, 2010, in Lalor, 2015). These "images of thought" that queer politics is vulnerable to could constrain the capacity for action when it seeks to think and "educate" on how a predestined "queer Arab" future should look like (in comparison to the temporally backwards present). So how can we think of concepts of the future within an affirmative Arab queer politics while avoiding the trap of "images of thought" 
and the teleological/progression narrative that reproduces liberatory/identity politics? A framework where time and futurity are non-linear and multidimentional could contribute to an understanding of politics that is not based on the dialectical and oppositional identity politics. Temporality should be understood as the potential for generative processes that are never achieved and that are not simply a replication of the past.

\section{Conclusion}

Drawing on the politics of the Meem community in Beirut, the ethics of a nomadic Arab queer subjectivity-in becoming rejects the moral universalism of the Gay International by arguing through the erotic/exotic paradigm. My affirmative approach of "different differences" challenges the assertion of culturally authentic sexual identities retained in the dichotomous framework of West/East, as depicted in the online response to the US-based marriage equality law. The non-fixed and imperceptible position of the group that instantiated on Facebook what I refer to as a queer Arab becoming is a weapon to reclaim erotic desire, which decolonizes and resists exoticization in the homonormative/homophobic discourses.

The close reading of a discussion with the Meem activists shows the tensions of a becoming, whether in its difficulties in defining what community and movement are, and in how it deploys relationality, affect, futurity, nomadism, and unpredictability. This community seems to be attempting to articulate the "spaces in-between" as spaces of encounter and of intensity as it is learning to speak a new language (Braidotti, 2011). In particular, the queer Arab's non-identitarian activism illustrated in the discussion thinks an erotic "different difference" of an affirmative queer politics in the Arab world. In untangling this question, the concept of politics of location, as argued by Braidotti, generates the grounding for political accountability based on a vision of the subject as nomadic and non-unitary, and hence is capable of stressing the complexity of future becomings of a queer Arab subject.

The micropolitics of political organizing, which I linked to Lorde's erotic force, defeats the logic of sameness. By highlighting the expression of minoritarian movements, the Meem encounter illustrates the deterritorialization and queering of macropolitics (Renold \& Ringrose, 2011, p. 396). It destabilizes the existing status quo by showing that activism cannot and should not be universalized. Instead, differences should be embraced since bodies are embedded and enfolded within spaces. The participants in the Meem encounter seem to be longing for a possible positive activity in the future in order to break the chain of "repetitionwithout-difference" (Braidotti, 2006, p. 154). Complexity, multiplicity and the quest for hybridity in sexuality activism are being thought of. Meem activists are expressing the absolute force of memory, which is the power to repeat the future. 


\section{References}

Abu-Odeh, L. (May 5, 2015). Holier Than Thou? The Anti-Imperialist Versus The Local Activist. 50.50 OpenDemocracy. Retrieved June 1, 2015 from https://www.opendemocracy.net/5050/lama-abuodeh/holier-than-thou-antiimperialist-versus-local-activist

Ahmed, S. (2010). Killing Joy: Feminism and the history of happiness. Signs, 35(3), 571-594.

Al-Qaws. (June 30, 2015). [Facebook update]. Retrieved June 30, 2015 from https://www.facebook.com/AlQawsorg/posts/933088683414515:0

Al-Nakib, M. (2013). Disjunctive Synthesis: Deleuze and Arab Feminism. Signs, 38(2), 459-482.

Amer, S. (2010). Joseph Massad and the Alleged Violence of Human Rights. GLQ: A Journal of Lesbian and Gay Studies, 16(4), 649-653.

Anderson, J. (2010). Crossing Swords: LGBTIQ NGOs in Lebanon, Joseph Massad's Critique, and Postcolonialism. (Doctoral dissertation). Retrieved October 15, 2015 from https://scholarworks.aub.edu.lb/handle/10938/8589

Asad, T. (2003). Formations of the Secular: Christianity, Islam, Modernity. Stanford University Press.

Bhabha, H. (1992). The World and the Home. Social Text, 141-153.

Braidotti, R. (2011). Nomadic Subjects: Embodiment and Sexual Difference in Contemporary Feminist Theory. Columbia University Press.

Braidotti, R., \& Dolphijn, R. (2014). Deleuze's Philosophy and the Art of Life Or: What does Pussy Riot Know? In This Deleuzian Century: Art, Activism, Life. Boston, Leiden: Brill Rodopi.

Deleuze, G., \& Guattari. F. (1980). A Thousand Plateaus. Trans. Brian Massumi. London and Minneapolis: University of Minnesota Press.

Deleuze, G., \& Guattari. F. (2009) Anti-Oedipus: Capitalism and Schizophrenia. Trans. Robert Hurley. New York: Viking Press, 1972.

Gregg, M., \& Seigworth, G. J. (2010). The Affect Theory Reader. Duke University Press.

Grosz, E. (2005). Time Travels: Feminism, Nature, Power. Duke University Press.

Habib, S. (2007). Female Homosexuality in the Middle East: Histories and Representations. New York: Routledge.

Hamdan, S. (2015). Re-Orienting Desire from With/In Queer Arab Shame: Conceptualizing Queer Arab Subjectivities through Sexual Difference Theory in a Reading of Bareed Mista3jil. Kohl: a Journal for Body and Gender Research 1(1), 54-69.

Haraway, D. (1988). Situated Knowledges: The Science Question in Feminism and the Privilege of Partial Perspective. Feminist studies, 575-599.

Joseph, S. (2012). Thinking Intentionality: Arab Women's Subjectivity and its Discontents. Journal of Middle East Women's Studies, 8(2), 1-25.

Kaplan, C. (1987). Deterritorializations: The rewriting of home and exile in western feminist discourse. Cultural Critique, 187-198.

Kilbride, E. (March 8, 2014). Lebanon Just Did a Whole Lot More Than Legalize Being Gay. Muftah. Retrieved June 28, 2015 from http://muftah.org/lebanon-just-whole-lot-legalize-gay/\#.VZDIw3TfraD

Lalor, K. (2015). Making Different Differences: Representation and Rights in Sexuality Activism. Feminist Legal Studies, 1-19. 
Leurs, K. H. A. (2012). Digital Passages. Moroccan-Dutch Youths Performing Diaspora, Gender and Youth Cultural Identities across Digital Space. Utrecht University.

Lorde, A. (1984). The Uses of the Erotic: The Erotic as Power. Sexualities and Communication in Everyday Life: A Reader. Lovaas \& Jenkins (Eds.) Thousand Oaks: Sage Publications, Inc, 87-91. Retrieved October 15, 2015 from http://uk.sagepub.com/sites/default/files/upm-binaries/11881_Chapter_5.pdf

Lynn (December 12, 2010). Framing Visibility: Coming Out and the International LGBT Spectrum of Progress. Bekhsoos. Retrieved October 15, 2015 from http://www.bekhsoos.com/2010/12/framing-visibilitycoming-out-and-the-international-Igbt-spectrum-of-progress-2/

Mahmood, S. (2005). Politics of Piety. The Islamic Revival and the Feminist Subject. Princeton University Press.

Makarem, G. (December 14, 2009). We Are Not Agents of the West: Ghassan Makarem Replies to Joseph Massad. Reset-DoC. Retrieved May 2, 2015, from http://www.resetdoc.org/story/00000001542

Marks, L. U. (2015). What Can a Body Do? Answers from Trablus, Cairo, Beirut and Algiers. Paragraph, 38(1), 118-135.

Mascat, J. M. (2015). Can the Subaltern Desire? Global Justice and Desire: Queering Economy. Dhawan et. al. (eds). Routledge.

Massad, J. (2007). Desiring Arabs. The University of Chicago Press.

Moussawi, G. (2015). (Un)critically Queer Organizing: Towards a More Complex Analysis of LGBTQ Organizing in Lebanon. Sexualities, 18(5-6), 593-617.

Muñoz, J. E. (2006). Feeling Brown, Feeling Down: Latina Affect, the Performativity of Race, and the Depressive Position. Signs, 31(3), 675-688.

Renold, E., \& Ringrose, J. (2011). Schizoid subjectivities? Re-theorizing Teen Girls' Sexual Cultures in an Era of 'Sexualization'. Journal of Sociology, 47(4), 389-409.

Saleh, F. (June 27, 2015). The most dangerous "unintended" consequence of the incredible hype on legalizing gay marriage in the U.S. is the immediate spread of the most subtle forms of censorship of dissent, on the one hand, and the immense, unprecedented pressure to CONFORM (a problem, ironically, LGBTIQs supposedly know too well and are still fighting against till now), on the other. [...] [facebook update]. Retrieved June 28, 2015 from https://www.facebook.com/fadi.saleh.399/posts/1146062098742513?fref=nf

Sanaa H. (2015). A Political Movement in Lebanon? A Conversation on Feminism and Queerness. Kohl: a Journal for Body and Gender Research 1(1), 92-104.

Shams, A. (June 30, 2015). Rainbow flag Covers Israeli Separation Wall near Ramallah. Mondoweiss. Retrieved June 30, 2015 from http://mondoweiss.net/2015/06/rainbow-separation-ramallah

Spivak, G. (1988). Can the Subaltern Speak? Marxism and the Interpretation of Culture. Nelson \& Grossberg (eds.). Urbana: University of Illinois Press, 271-313.

Taha, S. (April 21, 2013). Joseph Massad: an Occidentalist's Other Subjects/Victims. Arab Leftist. Retrieved May 2, 2015, from http://arableftist.blogspot.nl/2013/04/joseph-massad-occidentalists-other_21.html

Walker, R. L. (2014). The Living Present as a Materialist Feminist Temporality. Women: A Cultural Review, 25(1), 46-61. 